\title{
Karyotype for Nebo hierichonticus (Simon 1872) from the Palestinian Territories (Scorpiones: Scorpionidae)
}

\author{
Mazin B. Qumsiyeh ${ }^{1 *}$, Zuhair S. Amr ${ }^{2}$, Kareem T. Abu Srour ${ }^{1}$, and \\ Nael Al-Fawaghra ${ }^{1}$ \\ ${ }^{1}$ Faculty of Science, Bethlehem University and Palestine Museum of Natural History, \\ Bethlehem, Palestine \\ ${ }^{2}$ Department of Biology, Jordan University of Science and Technology, Amman, Jordan \\ Received September 14, 2013; accepted May 22, 2014
}

\begin{abstract}
Summary In this paper we report the first karyotypic data on Nebo hierichonticus (Simon 1872) from the occupied Palestinian territories. The karyotype consists of 50 chromosomes which appear acrocentric except for pair 3, likely representing the XY. With additional data on scorpionidae coming through, we suggest that a model of chromosomal evolution might involve changes in chromosome numbers that relate to chromosomal stability in the nucleus and recombination affecting adaptability as previously suggested and supported by studies of salmonid fish chromosomes.
\end{abstract}

Key words Karyotype, Nebo hierichonticus, Palestinian territory, Scorpion.

The order Scorpiones is a fascinating order of arthropods with over 2000 species. Its taxonomy continues to undergo revision, and new species are described as new data accumulate, including data on morphology and DNA analysis (e.g. Prendini et al. 2003, Sousa et al. 2011). In the Eastern Mediterranean region, some morphological work on scorpions was done by Vachon (1966, 1974), Levy and Amitai (1980), Lourenço (1999, 2002b), Amr and Al-Oran (1994), Kabakibi et al. (1999), and Stathi and Lourenço (2003).

A review showed that only about 80 of over 2000 known species of scorpions have been evaluated by chromosome studies (Moustafa et al. 2005, Schneider et al. 2009). We recently reported the karyotypes of three species from Palestine: Leiurus quinquestriatus, Hottentotta judaicus, and Scorpio maurus fuscus (Qumsiyeh et al. 2013). The only other study of chromosomes in the Middle East was done in Egypt of some members of the genus Androctonus, which had a fairly uniform $2 n=24$ (Moustafa et al. 2005).

Traditionally, Nebo hierichonticus was placed under the family Diplocentridae. However, Soleglad and Fet (2003) abolished this family and downgraded it to a subfamily rank in the family Scorpionidae. The karyotype of 15 species of this family was investigated, with $2 n$ ranging from 52 in Scorpio marus fuscus (Qumsiyeh et al. 2013) to 175 in Urodacus novaehollandiae (Shanahan 1989b).

In this paper, we report the first chromosomal data for Nebo hierichonticus, and we comment on the variation seen in chromosome number and possible evolutionary origin of this variation.

\section{Materials and methods}

The collection of scorpions was done during the day by turning rocks or objects where they

*Corresponding author, e-mail: mazin@qumsiyeh.org

DOI: $10.1508 /$ cytologia. 79.277 
Table 1. Locality coordinates from which Nebo hierichonticus were collected.

\begin{tabular}{lcc}
\hline \hline Locality & $\mathrm{N}$ & $\mathrm{E}$ \\
\hline Battir & $31^{\circ} 43^{\prime}$ & $35^{\circ} 08^{\prime}$ \\
Bil'in & $31^{\circ} 93^{\prime}$ & $35^{\circ} 07^{\prime}$ \\
EinFashkha & $31^{\circ} 42^{\prime}$ & $35^{\circ} 27^{\prime}$ \\
EinYabroud & $31^{\circ} 56^{\prime}$ & $35^{\circ} 15^{\prime}$ \\
Jebel KafrNe'mah & $31^{\circ} 93^{\prime}$ & $35^{\circ} 10^{\prime}$ \\
Wadi AlQuf & $31^{\circ} 34^{\prime}$ & $35^{\circ} 02^{\prime}$ \\
WadiFukeen & $31^{\circ} 71^{\prime}$ & $35^{\circ} 10^{\prime}$ \\
\hline
\end{tabular}

may hide, and during the night via walking and scanning the ground with ultraviolet flash lights. All specimens were retained in the nascent Palestine Natural History Museum (PMNH). Table 1 indicates the coordinates of localities from which materials were collected.

Karyotyping

Karyotyping was done from gonadal tissues dissected in saline solution by the method of Schneider et al. (2009). We found that the success rate is variable, and that it depends on the seasonality of reproduction in scorpions. Specimens collected in May to July gave us good results. For each specimen, at least five mitotic and/or meiotic cells were analyzed/counted.

\section{Results}

The karyotype for $N$. hierichonticus consists of 50 chromosomes. The chromosomes graded by size all appeared acrocentric with the exception of pair three, which in males appeared slightly heteromorphic, indicating it is likely the XY chromosome (Fig. 1). This is the first karyotypic data on $N$. hierichonticus.

\section{Discussion}

In Palestine, we reported the karyotypes of Hottentotta judaicus $2 n=16$, Leiurus quinquestriatus $2 n=22$, and Scorpio maurus fuscus $2 n=52$ (Qumsiyeh et al. 2013). The data above for Nebo adds an important element as it represents the first karyotype on the diplocentrid group within the Scorpionidae sensu lato.

Karyotypes of roughly $5 \%$ of the species of scorpions in the world are now available and show significant inter-genus and inter-specific variation (Schneider et al. 2009). However, our data on Nebo hierichonticus and a review of available data shows an interesting pattern - the karyotype of the Buthidae sensu lato ranges from $2 n=6$ to $2 n=48$, while that of the Scorpionidae sensu lata range from $2 n=29$ to $2 n=175$ (Shanahan 1989a, 1989b, Mattos et al. 2013). Schneider et al. (2009) stated that the low diploid numbers were restricted to the most cytogenetically investigated family (Buthidae) and in Opiliones, but not in the Scorpiones groups. There are complications to studying chromosomes of scorpions. Parthenogenesis was noted in some species including a number of species of Tityus (Lourenço 2002b). Other species (e.g. Urodacus novaehollandiae) were noted to have high chromosome numbers, perhaps suggesting polyploidy (Shanahan 1989a). Even if we exclude those two phenomena, we still have to explain why there is such a high variation in chromosome numbers.

Schneider et al. (2009) does not explain the possible evolutionary advantage of chromosome number in scorpions. Qumsiyeh $(1994,1995)$ proposed a model in which increases and decreases in chromosome number in mammals are selected based on their effect on recombination and stability 


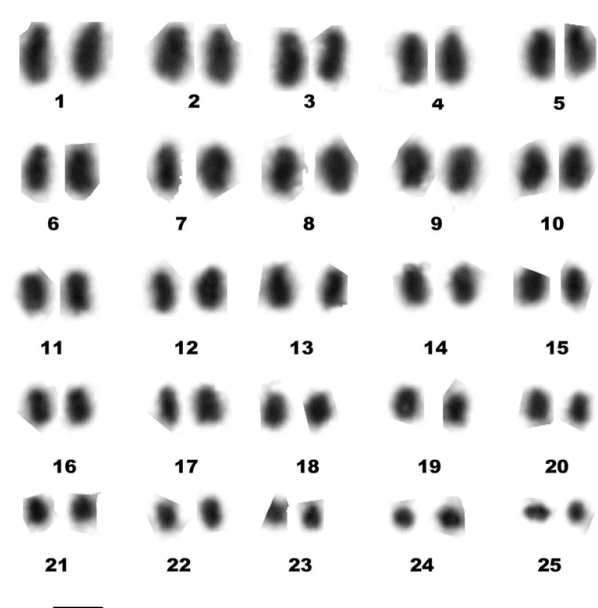

A

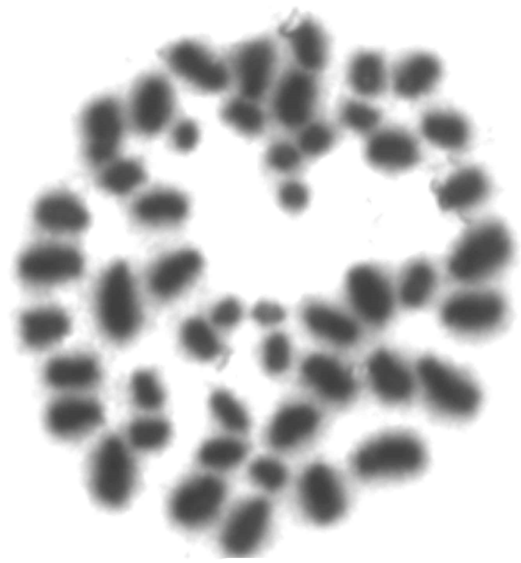

B

Fig. 1. A. Karyotype and B. metaphase of a male N. hierichonticus from Battir. Pair 3 is likely the XY. $\mathrm{Bar}=2 \mu \mathrm{m}$.

of chromosomes in interphase nuclei. The model seemed useful to explain chromosomal variation in salmonid fish (Phillips and Ráb 2001), and it would be interesting to study its applicability in scorpions, especially as more ecological and reproductive data are collected.

Most of the reported species of Buthidae sensu lata are apoikogenic, while most of the reported species of Scorpionidae sensu lata are katoikogenic in the sense that was developed by Laurie (1896). The phylogenetic difference remains if we take the modifications of this classification of apoikogenic and katoikogenic by Lourenço et al. (1986), Lourenço (2002a) and Warburg (2010). Lourenço et al. (1986) suggested that the Buthidae have the most complex gradient of embryonic development, while Scorpionidae species have less complexity. Variables like adaptability to different habitats and reproduction strategies should be correlated to karyotypic data in species of scorpions to understand evolutionary strategies. Better understanding of these strategies will come as more data accumulate including better phylogenetic trees based on molecular data.

\section{References}

Amr, Z. S. and Al-Oran, R. 1994. Systematics and distribution of scorpions (Arachnida, Scorpionida) in Jordan. Boll. Zool. 61: 185-190.

Kabakibi, M. M., Khalil, N., and Amr, Z. 1999. Scorpions of Southern Syria. Zool. Middle East 17: 79-89.

Laurie, M. 1896. Notes on the anatomy of some scorpions, and its bearing on the classification of the order. Ann. Mag. Natr. Hist. Ser. 6 17: 185-194.

Levy, G. and Amitai, P. 1980. Fauna Palaestina. Arachnida I: Scorpiones. The Israel Academy of Science and Humanities, Jerusalem.

Lourenço, W. R. 1999. On the phylogenetic position of the genus Birulatus Vachon, 1973 (Scorpiones, Buthidae) and redescription of Birulatus haasi. Zool. Middle East 18: 109-113.

Lourenço, W. R. 2002a. Further morphological considerations on the genus Birulatus Vachon (Scorpiones, Buthidae), with the description of a new species from Israel. Revista Iberica de Aracnologia 6: 141-145.

Lourenço, W. R. 2002b. Reproduction in scorpions, with special reference to parthenogenesis. In: Toft, S. and Scharff, N. (eds.). Proceedings of the 19th European Colloquium of Arachnology, European Arachnology 2000. Aarhus University Press, Aarhus. pp. 71-85.

Lourenço, W. R., Kovoor, J., and Muñoz-Cuevas, A. 1986. Morphogenèse des premiers stadesembryonnaires chez des Scorpions. Boll. Zool. 53: 105.

Mattos, V. F., Cella, D. M., Carvalho, L .S., Candido, D. M., and Schneider, M. C. 2013. High chromosome variability and 
the presence of multivalent associations in buthid scorpions. Chromosome Res. 21: 121-136.

Moustafa, M. A., Alaa, A. M., Sarhan, M. H., and Yaseen, A. E. 2005. Chromosomal studies on four Egyptian scorpion species of genus Androctonus (Family: Buthidae). Cytologia 70: 161-165.

Phillips, R. and Ráb, P. 2001. Chromosome evolution in the Salmonidae (Pisces): An update. Biol. Rev. Camb, Philos. Soc. 76: $1-25$.

Prendini, L., Crowe, T. M., and Wheeler, W. C. 2003. Systematics and biogeography of the family Scorpionidae Latreille, with a discussion of phylogenetic methods. Invertebr. Syst. 17: 185-259.

Qumsiyeh, M. B. 1994. Evolution of number and morphology of mammalian chromosomes. J. Hered. 85: 455-465.

Qumsiyeh, M. B. 1995. Impact of rearrangements on function and position of chromosomes in the interphase nucleus and on human genetic disorders. Chromosome Res. 3: 455-465.

Qumsiyeh, M. B., Salman, I. N.A., Salsaa', M., and Amr, Z. S. 2013. Records of scorpions from the Palestinian Territories, with the first chromosomal data (Arachnida: Scorpiones). Zool. Middle East 59: 70-76.

Schneider, M. C., Zacaro, A. A., Pinto-Da-Rocha, R., Candido, D. M., and Cella, D. M. 2009. A comparative cytogenetic analysis of 2 Bothriuridae species and overview of the chromosome data of scorpiones. J. Hered. 100: 545-555.

Shanahan, C. M. 1989a. Cytogenetics of Australian scorpions. I. Interchange polymorphism in the family Buthidae. Genome 32: 882-889.

Shanahan, C. M. 1989b. Cytogenetics of Australian scorpions. II. Chromosome polymorphism in species of Urodacus (family Scorpionidae). Genome 32: 890-900.

Soleglad, M. E. and Fet, V. 2003. High-level systematics and phylogeny of the extant scorpions (Scorpiones: Orthosterni). Euscorpius 11: 1-175.

Sousa, P., Froufe, E., Harris, D. J., Alves, P. C., and Van Der Meijden A. 2011. Genetic diversity of Maghrebian Hottentotta (Scorpiones: Buthidae) scorpions based on CO1: New insights on the genus phylogeny and distribution. Afr. Invertebr. 52: 135-143.

Stathi, I. and Lourenço, W. 2003. Description of a new scorpion species of the genus Birulatus Vachon, 1974 (Scorpiones, Buthidae) from Syria. Zool. Middle East 30: 105-110.

Vachon, M. 1966. Liste des scorpions connus en Egypte, Arabie, Israel, Liban, Syrie, Jordanie, Turquie, Irak, Iran. Toxicon 4: 209-218.

Vachon, M. 1974. Etude des caracteres utilises pour classer les familles et les genres de Scorpions (Arachnides). Bull. Musé. Nat. Hist Natur, Paris 3: 857-895.

Warburg, M. R. 2010. Reproductive system of female scorpion: a partial review. Anat. Rec. 293: 1738-1754. 